\title{
O QUE É MEU É MEU, O QUE É SEU É NOSSO \\ Questões DE/SOBRE CIDADE DE DEUS
}

por Keila Prado Costa $^{1}$

\begin{abstract}
RESUMO: O romance de Paulo Lins, Cidade de Deus, teve um processo de criação bastante curioso. Suas duas edições tiveram obras de outros autores como ponto de partida - ou mudança - para a escritura. A primeira tomou a pesquisa e a obra de Alba Zaluar como fonte e inspiração. A segunda utilizou a obra cinematográfica de Fernando Meirelles como motivo de revisão. Além disso, tanto na escritura como na recepção do livro, o crítico literário, Roberto Schwarz, teve um papel de grande importância, o que nos leva a algumas indagações acerca da relação entre literatura e crítica.

PALAVRAS-CHAVE: Cidade de Deus, Favela, Processo de Criação, Literatura e Crítica.
\end{abstract}

RESUMÉ: Le roman de Paulo Lins, La Cité de Dieu, a eu un processus de création suffisamment curieux. Leurs deux éditions ont eu des oeuvres d'autres auteurs comme point de départ - ou changement - pour l'écriture. La première édition a pris la recherche et l'oeuvre d'Alba Zaluar comme inspiration pour écrire le roman. La seconde a utilisé l'oeuvre cinématographique de Fernando Meirelles comme point de révision. En outre, dans l'écriture e dans la réception du livre, le critique littéraire, Roberto Schwarz, a eu un rôle très important, ce qui pose quelques questions sur la relation entre la littérature et la critique.

MOTS CLÉS: Cidade de Deus, favela, procès de création, littérature et critique.

Para falar sobre algumas questões que envolvem a criação e a recepção do romance de Paulo Lins, Cidade de Deus, é necessário observar primeiro o desenvolvimento de uma história:

"Cidade de Deus" é hoje um nome de sucesso e de muitos referentes - tanto para o bem quanto para o mal. Com 40 anos de notícias, já ocupou diversas páginas dos jornais. Primeiro, em cadernos sobre o cotidiano urbano; depois, em cadernos policiais. Quando todos já estavam acostumados a ler matérias sangrentas envolvendo os habitantes de lá, os habitantes se tornaram personagens, as notícias saltaram algumas páginas e se instalaram nas seções culturais, em resenhas e em ensaios literários e cinematográficos, chegando enfim à famosa lista de indicações ao Oscar.

Mas como todo esse processo de transição aconteceu?

Tudo começou em 1966, quando a prefeitura da cidade do Rio de Janeiro transferiu moradores de diversas favelas cariocas - que haviam sido destruídas por fortes chuvas - para um Conjunto Habitacional oficialmente batizado como "Cidade de Deus" 2 ". Com a infra-estrutura que possuía - muito superior a das favelas da época - "Cidade de Deus" realmente parecia ser um lugar divino. No entanto, como nem tudo é o que parece, a falta de manutenção e de organização, acabou por transformar o conjunto em mais uma favela ${ }^{3}$.

\footnotetext{
${ }^{1}$ Mestranda da área de Língua e Literatura Francesa da Universidade de São Paulo. Membro do grupo Criação $e$ Crítica.

${ }^{2}$ O conjunto habitacional Cidade de Deus foi construído durante os anos de governo de Carlos Lacerda, entre 1962 e 1965 .

3 "No começo parecia até sonho, a gente nem acreditava. As casas ficavam longe de tudo mas eram todas novinhas e com serviços aparentemente eficientes. (...) Pena que era tudo só aparência, as coisas foram ficando esquecidas e não
} 
A partir daí, iniciou-se um processo de transição e transmutação desse referencial (o espaço físico favela) em diversos referentes. O Conjunto Habitacional que virou Favela, virou Tese Antropológica, que virou Romance, que virou Filme, que virou Romance de novo - e nessa "viração" toda se manteve com ruas e barracos, com pessoas, personagens e muitas histórias. E foram todas essas histórias, contadas de diferentes maneiras, por diferentes vozes, que provocaram o interesse da crítica e, conseqüentemente, a reflexão aqui construída ${ }^{4}$.

O romance de Paulo Lins é fruto e causa, simultaneamente, dessa "viração". Fruto, porque Lins o escreve tomando como ponto de partida sua própria experiência na favela como morador e como pesquisador de um projeto de antropologia coordenado por Alba Zaluar; e causa, porque a partir do texto literário surge o filme dirigido por Fernando Meirelles e Katia Lund que, por sua vez, contribui para uma nova edição do romance, revista pelo autor.

Essas obras foram, no cenário político e artístico brasileiro, no mínimo, provocantes. Suscitaram discussões entre moradores da favela, intelectuais, jornalistas, críticos, acadêmicos, artistas e membros do poder público, acerca de temas como: crime, criminalidade, representação, apropriação da realidade, ficção, banalização dos problemas nacionais, etc. Essas discussões não chegaram a nenhum resultado específico, mas apresentaram muitos pontos de reflexão.

Neste texto, queremos retomar algumas das discussões que envolvem o processo de criação literária de Cidade de Deus e sua recepção pela crítica nacional. Para isso, observaremos como ponto de partida a nota que o autor coloca ao final da $1^{\mathrm{a}}$ edição do romance, pois ele nos dá algumas pistas sobre a gênese do romance. A partir dessas pistas, buscaremos estruturar a cronologia e alguns aspectos do processo de escritura de Cidade de Deus:

Este romance se baseia em fatos reais. Parte do material utilizado foi extraído das entrevistas feitas para o projeto "Crime e criminalidade nas classes populares", da antropóloga Alba Zaluar, e de artigos nos jornais $O$ Globo, Jornal do Brasil e $O$ Dia.

Mais especificamente, a primeira parte do livro foi escrita enquanto se desenvolviam os projetos de pesquisa "Crime e Criminalidade no Rio de Janeiro" (que contou com o apoio da FINEP) e "Justiça e classes populares" (apoio CNPq, FAPERJ e FUNCAMP), ambos coordenados por Zaluar. A própria idéia do romance surgiu no decorrer dos trabalhos ligados ao projeto, a partir do momento em que a coordenadora começou a redigir seus artigos. Trabalhei com ela durante oito anos, e agradeço seu incentivo constante.

A segunda e a terceira partes do romance foram concebidas com o apoio precioso de Roberto Schwarz, Virgínia Oliveira Silva e Maria de Lourdes da Silva. Devo a Roberto Schwarz, em especial, a orientação e o incentivo em relação a minha candidatura à Bolsa Vitae de Artes.

Agradeço, finalmente, à Fundação Vitae que, concedendo-me uma bolsa, deume condições de acabar de escrever o romance e dar ao texto sua forma final (LINS, 1997, p. 549).

tinha manutenção. Alegria de pobre dura pouco". (Maria Theresinha de Jesus - presidente da associação de moradores da Cidade de Deus nos anos 80. Rede Internet, site www.favelatemmemoria.com.br).

${ }^{4}$ Como já foi enunciado, meu objetivo neste artigo é a observação do texto literário Cidade de Deus (das duas versões publicadas do romance - 1997 e 2002), mas para realizar essa empreitada, não posso me furtar ao diálogo com os outros referentes: o trabalho de Alba Zaluar em A Máquina e a Revolta, e o filme dirigido por Fernando Meirelles, baseado no romance de Paulo Lins, também com o título Cidade de Deus (2002), pois esses trabalhos são vozes muito importantes de toda essa história. 
Paulo Lins vivia na favela carioca nos anos 80, quando Alba Zaluar conduziu a pesquisa antropológica "Crime e Criminalidade nas Classes Populares". Foi escolhido para ser um de seus colaboradores porque cursava o ensino superior e conhecia bem a favela. Essa experiência foi fundamental para a construção do romance. Nos oito anos em que participou da pesquisa, Lins colheu material, participou de discussões e, mais do que qualquer outra coisa, ouviu muitas conversas. A condensação desse material o levava a escrever - mas não os relatórios "científicos" que supostamente se apresentariam nesse tipo de pesquisa acadêmica. Lins escrevia textos literários:

Enfim, eu sabia muito e tinha acesso aos bandidos, o que ajudou meu trabalho com a Alba. (...) Mas Alba, vendo que eu fazia etnografias ruins, me pediu para eu escrever alguma coisa sobre a minha vida, em prosa ou em poesia mesmo. Ela sacou que meu negócio era com as letras, não com a antropologia (PORTAL LITERAL, 2003).

De fato, Zaluar estava certa. Lins realmente tinha muito mais intimidade com o mundo das Letras que com o da Antropologia, não só porque este era seu curso de graduação, mas também porque nessa época escrevia poemas e sambas-enredos para as escolas de samba de sua comunidade. Com essa "licença-poética" concedida por Zaluar, Lins começou a escrever sobre a "Cidade de Deus" sob um novo viés. Nasciam aí os primeiros rascunhos do que anos depois se tornaria um romance.

Dos primeiros rascunhos - em prosa ou em poesia escritos para o projeto de Alba Zaluar até a publicação da primeira edição de Cidade de Deus, transcorreram-se mais de dez anos. O que nos chama a atenção, no entanto, é que o trabalho de escritura e publicação do texto ao longo desses anos deu-se de um modo inusitado:

Ela [Alba Zaluar] levou para o Roberto Schwarz ver [levou os textos literários que Paulo produzia no lugar das etnografias]. Morri de medo. Ele tinha acabado de ser indicado como o "Intelectual do Ano" pelo JB. Era o superstar do momento. Roberto lê, liga pra mim, e me chama a São Paulo porque queria conversar comigo. Ele falou assim: "O seu poema está muito legal, mas você deve escrever um romance. Eu te arranjo uma bolsa para escrever esse romance". E eu estava duro.... Aí eu fui para casa e comecei a escrever o romance "Cidade de Deus". E eu não tinha a menor idéia de como se escrevia uma [sic] romance. Minha referência era a poesia, porque havia aquela polêmica na época e eu participava dela. O romance seguia a linha modernista sem grandes conflitos. Achei que ia ser difícil eu escrever um romance. Aí comecei a falar com os amigos. Paulo Futeco, um amigo meu que fazia farmácia e hoje trabalha com publicidade, sugeriu: "Rapaz, faz um romance sem personagem. Ou faz personagens numerados". Todo mundo esperava que eu fizesse alguma coisa que fosse diferente. Que fosse "pós" (PORTAL LITERAL, 2003) 5

Deixar de escrever poemas para escrever um romance é realmente uma mudança e tanto, ainda mais quando há pressões de todos os lados para que o resultado deste trabalho seja algo importante, impactante. Paulo Lins não se intimidou e iniciou o romance de uma maneira bastante peculiar:

\footnotetext{
${ }^{5}$ As informações entre colchetes são informações e explicações minhas.
} 


\begin{abstract}
Heloísa Buarque de Hollanda: Mas você não botou os números, botou o quê então?

PAULO LINS: Botei um monte de gíria. Saí procurando gíria, pegando a linguagem, tudo o que se falava na Cidade de Deus e não se falava fora.
\end{abstract}

HBH: E você foi pela linguagem off.

PAULO: É. E fui trabalhando o vocabulário, as palavras que só eram usadas lá, fui juntando tudo e saquei que o assunto lá tinha que ser o crime... E não parava de ler desesperadamente poesia. Comecei tentando fazer variações com os versos dos poemas. E quando eu vi a tradução do Maiakovski do Haroldo de Campos e do Décio Pignatari, eles diziam que Maiakovski fazia 60 variações do mesmo verso. Sabe, o cara batalhava! Era aquela coisa do labor da poesia...90\% da poesia era transpiração, o resto é inspiração... E eu fiquei com isso na cabeça e comecei a fichar romance. Na realidade, eu reescrevia os romances que admirava. Eu pegava os capítulos e ia fazendo mutações no texto. Eu reescrevi o "Fogo morto" inteiro. Fiquei seis meses mentindo para a Alba: olha, já escrevi isso tudo. E era o "Fogo morto". Aquele romance do José Lins do Rego é maravilhoso, me deixou louco com o sentimento pela linguagem. Porque o Roberto falou uma coisa: "Ô, Paulo, põe sentimento". Então eu roubei passagens inteiras do "Fogo Morto". Quando o Mané Galinha vê o irmão dele morto, é a mesma coisa de quando o Lula Chacon de Holanda fala pro Mestre José Amaro: "Vai embora da minha fazenda!" E ele pega e sai, falando assim: "Vai passando assim pela estrada, com o diabo no seu coração batendo forte..."

\title{
HBH: Isso é lindo!
}

PAULO: E não precisa dizer mais nada, o sentimento dele está ali. Então, o Mané Galinha também sai "com uma tocha de fogo na mão para incendiar a casa do assassino do seu irmão com o diabo no seu coração batendo forte". Eu nunca falei disso para ninguém, mas está tudo lá, no meu computador.

\section{HBH: Paulo, você é um pós-moderníssimo ...}

PAULO: Fiz isso com muitos romances. No "Crime e castigo", o Dostoiévski começa o romance planejando e contando como ele vai matar a velha proprietária avarenta da casa onde mora o personagem central. Eu fui pegando só os trechos em que ele bolava esse assassinato, dividi em vários e coloquei no computador. E botei isso em "Cidade de Deus" no episódio do sujeito que mata por vingança o filho, porque ele era preto e o filho nasceu branco. Essa parte é igual à do Raskolnikov. Então é isso. Roubei e é meu! Ninguém viu, e se eu não falar ninguém vai saber.

HBH: Genial! Porque isso no fundo é o ato de fazer literatura, mas de uma forma inconsciente ou oculta. No seu caso é diferente, você age como um pivete e não como um "polifônico".

PAULO: É porque romance é diferente de poesia. Poesia é mais fácil, você gosta de uma palavra, começa um poema. E você fica com aquela palavra, ela se finca ali, você vai fazendo no ônibus, na bicicleta... Romance não, você tem que se sentar, escrever todo dia (PORTAL LITERAL, 2003).

As revelações que Lins faz de seu processo de criação a Heloisa Buarque de Hollanda são realmente surpreendentes. Quantas pessoas notariam esses fatos? Quantos escritores revelariam esses caminhos de escritura tão naturalmente? É possível dizer que o processo de criação de Cidade de Deus é, no mínimo, muito complexo. Ele movimenta toda a questão de escritura e reescritura do texto, mas como dissemos acima, descreveremos aqui apenas alguns pontos de 
tensão dessa obra que, num trabalho mais amplo, poderão ser analisados com detalhes, trazendo à luz novos olhares sobre a literatura brasileira.

\section{CRIAÇÃO E CRÍTICA: ONDE UMA COMEÇA A OUTRA TERMINA?}

A partir do relato de Paulo Lins para Heloísa Buarque de Hollanda, podemos levantar as seguintes indagações: o que é o labor literário? O que é criação? Qual é a diferença entre intertextualidade, polifonia, plágio...? Qual é a função da crítica em relação à literatura? O que difere exatamente uma da outra? A crítica vem antes ou depois do texto literário?

Dizem que os grandes escritores são, antes de qualquer coisa, grandes leitores. Sem dúvida, a leitura desperta o ato de pensar sobre as palavras, sobre seus significados e sobre o modo como a articulação delas entre si produz resultados diferentes. No caso de Paulo Lins, apenas pelo relato acima, não podemos afirmar que ele seja um grande leitor, mas é fato que seu desejo por escrever um romance o levou à prática da leitura de modo bastante intenso - a ponto de levá-lo a reescrever um romance já consagrado.

Esse trabalho de Lins foi extremamente importante, pois foi o que lhe deu subsídios para encontrar a forma do romance - da escritura do romance - já que esse era um desafio. Uma vez encontrado esse modo de escrever em prosa, era hora de aplicar o conteúdo, ou seja, as histórias e o enredo em si, com todas as suas questões e transpirações.

E o conteúdo estava lá, praticamente pronto, pois o material que Lins ajudara a recolher, durante os anos do trabalho com Zaluar, apresentava não só os temas que fundamentaram o romance - como a descrição da geografia de Cidade de Deus e a guerra entre Zé Pequeno e Mané Galinha - mas também, uma fonte de múltiplas perspectivas, já que com seu trabalho Zaluar pôde apresentar como viviam e se relacionavam os trabalhadores, os policiais, os bandidos, as mulheres e as crianças da Cidade de Deus.

Paulo Lins utiliza esse material tal como Zaluar. No entanto, ele utiliza sua vivência no local e o testemunho de muitas pessoas para dar forma a um romance, enquanto ela descreve uma experiência própria, de pesquisadora, em primeira pessoa, dando interpretações e explicações científicas ao seu convívio como antropóloga com os moradores do local e do convívio deles entre si.

Zaluar fala do passado como passado e do presente como presente. Lins transfere passado e presente para o tempo da narrativa, para o tempo da ficção. Assim, mesmo sendo baseado em fatos reais, o livro compreende a dimensão do texto literário, e mesmo apresentando características de documentário jornalístico, impõe-se por meio de uma narrativa romanesca.

Vejamos esses trechos do livro de Zaluar, A Máquina e a Revolta, que foi publicado primeiramente em 1985, logo após a defesa de sua tese na Universidade de São Paulo, e comparemos com alguns trechos do romance: 
Foi da época da guerra entre a quadrilha de Manoel (da quadra) com a de Zé Pequeno (dos apartamentos) e a de Timbó (das casas de triagem da quadra 13) que me ficaram as representações que mais claramente associavam a "área" ou o "pedaço" a seus defensores "bandido". Nesta representação positiva dos bandidos, os moradores os consideram como o vingador de seu povo, do seu "pedaço", e o defensor da inviolabilidade do território que ocupam. São eles que efetivamente impedem a entrada de outros bandidos, pivetes, ladrões ou estupradores que não só ameaçariam a segurança dos trabalhadores como manchariam a honra e a dignidade dos moradores daquele local. É essa associação que lhes permite distinguir entre o "bandido formado", isto é, o que conhece as regras do jogo e não ultrapassa os limites de sua atuação, garantindo o respeito e proteção entre moradores, e demais bandido. Um bandido "formado" não mexe com o trabalhador de sua área, mas o respeita e o defende nesse vácuo deixado por uma ação policial e judiciária ineficiente e pervertida. É precisamente isso a simbiose entre eles, esse infeliz mas necessário casamento. Sobre Manoel ouvi:

“...ele não tinha medo, enfrentava eles todinho e não tinha medo, então ele era um cara que tem o nome na história, então a vila ficou famosa como vila do Mane Galinha, embora ele já esteja no mundo espiritual...

De um dirigente do bloco, trabalhador digno e respeitado, ouvi:

Sugestão no modo deles dizer é uma ordem: 'bota no chão que eu vou levar'. Ou puxa o relógio ou tira uma bolsa, com a arma apontada pra você. Vai fazer o quê? Agora manda eles vim fazer isso na mão, com toda a minha magreza.Entendeu como é que é? Eles não vem. Porque o bandido é o eterno covarde.

Essas expressões são contrastadas a "dar uma idéia", "trocar idéias", que são usadas quando alguém tenta convencer outra pessoa de algo através do diálogo, da força das palavras persuasivas. Assim, os trabalhadores parecem distinguir e opor claramente a força do sentido ou o poder simbólico à força bruta, o que é
No dia 27 de setembro, Pequeno e Bené ganharam a admiração dos moradores dos apartamentos pela festa realizada na praça dos Apês. Envaidecidos pela lembrança da data com os festejos merecidos pela ocasião e pelo agrado às suas crianças, retribuíram com consideração. Nos dias decorrentes, Pequeno e Bené tiveram a impressão de que todos os moradores os olhavam com gratidão, porque não foram poucas as benfeitorias promovidas pela dupla: acabaram com os roubos, os assaltos, os estupros na favela, e agora davam doce. Os balões apagados continuavam a ser permitidos, nesses casos a punição recaía sobre o bêbado. Muitos biriteiros passaram a beber menos, para a alegria das donas de casa.

Galinha passou os dois dias acordado, ando por entre os becos lá de cima, indumentária militar, cabelo desgrenhado, seus olhos azuis brilhando. Muitas pessoas o saudavam, a mulherada que não o conhecia, ouvindo falar de sua beleza e valentia, montava guarda na esquina na esperança de vê-lo.

Ao contrário do que pensava Galinha, o apoio do pessoal de Lá de Cima foi grande.

Subitamente, Sandro colocou o cano do revólver na cabeça de Sidney.

- Diz aí qual foi a idéia que teu macho mandou você me dar!?

- Que, que, que...!?

- Quiquiqui é o caralho, rapá! Fala, senão tu vai morrer! - disse Cenoura e apalpou a cintura do avião até encontrar seu revólver.

- Falou pra tu matar ele, senão ele ia tomar tua boca.

Galinha balançou a cabeça e disse:

- Sai dessa rapá. Tu é novinho, fica fazendo o jogo daquele maníaco. Não sei o que vocês têm na cabeça!

- Eu sei! Tem teleguiação! - disse Cenoura e deu um tiro de raspão nas nádegas de Sidney. E completou: - Vai lá e avisa a teu macho que quem manda aqui em cima agora é Cenoura e Mané Galinha! Filho da Puta!

(Lins, Paulo. Cidade de Deus. $1^{\mathrm{a}}$ edição. Companhia das Letras: São Paulo, 1997.) 
corroborado ainda mais pela oposição que fazem entre "vencer na moral" e "vencer na covardia". É dessa maneira concreta, prática, colada à sua experiência cotidiana, que diferenciam o que poderíamos chamar arbítrio ou autoritarismo da democracia, ou a relação de dominação da competição justa e legítima entre iguais. Ao invés de uma idéia abstrata de justiça ou de democracia, no entanto, guiam-se por uma idéia retirada de suas próprias experiências, segundo a qual avaliam ou julgam o comportamento daqueles que têm contato pessoal direto. Como seria de se supor, não só os bandidos têm sua conduta depreciada porque se impõem através da "sugestão". Os policiais, até 1983, eram criticados "por irem logo dando sugestão", sem nem conversar. A visão negativa tanto de bandidos quanto de policiais está aí enraizada.

(Zaluar, Alba. A Máquina e a Revolta. $2^{\mathrm{a}}$ edição. São Paulo: Brasiliense, 2000. Págs. 138, 139, 140 e 141.)

Pela proximidade com o resultado da pesquisa antropológica, Cidade de Deus - o romance - foi recebido por parte da crítica como uma espécie de extensão do trabalho de pesquisa de Alba Zaluar, tornando-se quase uma ficcionalização da experiência de observação científica. Por esse motivo, segundo alguns críticos, a maior virtude que a obra tem é a apresentação dos fatos de um ponto de vista interno.

Essa característica foi pontuada em especial por Roberto Schwarz e Vilma Areas, logo após o lançamento da primeira edição do romance. Eles não citam, ou melhor, não avaliam e analisam a herança que Lins tem de Zaluar, mas percebem que a focalização narrativa vem de dentro das personagens e de dentro do espaço que elas habitam e, talvez, do próprio escritor:

O romance de estréia de Paulo Lins, um catatau de quinhentas e cinqüenta páginas sobre a expansão da criminalidade em Cidade de Deus, no Rio de Janeiro, merece ser saudado como um acontecimento. $\mathrm{O}$ interesse explosivo do assunto, o tamanho da empresa, a sua dificuldade, o ponto de vista interno e diferente, tudo contribui para a aventura artística fora do comum. A literatura no caso foi levada a explorar possibilidades robustas, que pelo visto existem (SCHWARZ, 1999).

O que faz toda a diferença de Cidade de Deus do ponto de vista literário é que a afirmação da violência, a tensão desesperada e as formas espectrais e desgarradas, delirantes pela fome ou pela droga (identidades na melhor das hipóteses coladas aos heróis televisivos) sejam narradas a partir de um ponto de vista interno e de classe (observação de Roberto Schwarz), colhidas em muitas perspectivas (conforme vimos nas citações de Marreco e Soninha Maravilhosa) e representadas a partir de distâncias diferentes que refluem para a voz que narra. 
Porque experimenta, essa voz está colocada às coisas cotidianas, isto é, não precisa do apoio do exotismo - a insistência lírica o substitui com vantagem - e resolve de modo particular a estilização ficcional (AREAS, 1998).

A partir dessas leituras começa a se formar a fortuna crítica do romance, e claro, os diferentes posicionamentos frente a ele. A situação muda um pouco com o lançamento do filme em $2002^{6}$ - quando a crítica volta-se inteiramente para a obra cinematográfica, pois mesmo depois do lançamento da segunda edição do livro, o filme manteve-se como maior ponto de observação.

Desse modo, a fortuna crítica de Cidade de Deus pode ser dividida em dois grandes grupos: antes e depois do filme. O interessante, no entanto, é observarmos como a produção do filme foi determinante para que houvesse a revisão do romance e como, concomitantemente, há uma situação de envolvimento e distanciamento da crítica em relação ao processo de criação da obra literária.

Para isso, é importante ilustrarmos aqui algumas particularidades existentes em cada uma dessas edições da obra de Paulo Lins antes de continuarmos a exposição sobre a crítica de Cidade de Deus. Em sua edição de 2002, o romance apresenta um corte de mais de 100 páginas em relação à primeira edição. Esse corte implica na supressão de personagens e de algumas histórias. Além disso, da edição de 1997 para a edição de 2002, Lins muda o nome de diversas personagens do romance, dentre elas, muitas que protagonizam boa parte das histórias - tanto na primeira edição, quanto no filme ${ }^{7}$ :

\section{Cidade de Deus - $1^{\text {a }}$ Edição, $1997^{8}$}

Cabeleira, Carlinho Pretinho, Pelé e Pará pararam no matagal. Uma cobra saiu de fininho. Dois tatus fizeram um pequeno barulho ao se retirarem. Era hora de ajeitar o roubo, dividi-lo mesmo sem contar o dinheiro e averiguar o valor das jóias, porque se sujasse, para quem estivesse com o flagrante, tudo estava perdido.

- Dadinho deve ter dançado. Eu não queria ter trazido esse moleque, morou, cumpádi? - disse Cabeleira enquanto enxugava o suor do rosto. E continuou: Já que o bicho pegou, é melhor nós ir pra Deus mermo.

- Que nada, rapá! Vamo sair saindo pro Salgueiro porque nós pode...

- Vai ganhar um carro agora com os homi na nossa captura? - interrompeu Cabeleira com voz autoritária. Voltaram a andar pelo mato por algum tempo calados. Depois de passarem pelo campo do Paúra, Cabeleira afirmou que teriam de guardar a parte do Dadinho e, se por acaso ele tivesse dançado, mandariam o dinheiro para a cadeia.

\section{Cidade de Deus - Roteiro do Filme, 2003 (Filme, 2002)}

\footnotetext{
${ }^{6}$ Cidade de Deus - filme. Direção: Fernando Meirelles. Co-direção: Katia Lund. Roteiro: Bráulio Mantovani.

${ }^{7}$ Ressalto aqui que o filme foi baseado na primeira edição do livro e que segunda edição foi revista em virtude da estréia do filme em todo país. Segundo Paulo Lins, "Literatura é literatura, filme é filme. Quis afastar o livro do filme para o pessoal procurar qual personagem está ou não - diz Paulo Lins." (Vida na periferia ganha espaço na literatura. por Patrícia Rocha, Jornal Zero Hora, 9/11/2002).

${ }^{8}$ Os grifos em negrito e itálico são meus e marcam as mudanças e supressões.
} 


\section{ESTACIONAMENTO DO MOTEL - NOITE \\ CABELEIRA}

Aí, pega o carro que eu vou atrás do Dadinho.

\section{MARRECO}

Vam'bora.

\section{ALICATE}

Que carrão!

Os bandidos entram num carro bem apertado e Alicate sai guiando mal de um dos boxes.

\section{NA SAÍDA DO MOTEL - NOITE}

O carro breca seco ao lado de Cabeleira, que olha para os lados procurando Dadinho.

\section{CABELEIRA}

Babou, o Dadinho sumiu.

Cabeleira entra no carro. TIROS.

\section{MARRECO}

Que se foda. Ele saiu atirando, vam'bora.

\section{Cidade de Deus - 2a Edição, 2002}

Inferninho, Carlinho Pretinho, Pelé e Pará pararam no matagal. Era hora de ajeitar o roubo, dividi-lo mesmo sem contar o dinheiro e averiguar o valor das jóias, porque se sujasse, para quem estivesse com o flagrante, tudo estaria perdido.

- Inho deve ter dançado. Eu não queria ter trazido esse moleque, morou, cumpádi? - disse Inferninho enquanto enxugava o suor do rosto. E continuou: Já que o bicho pegou, é melhor nós ir pra Deus mermo.

- Que nada, rapá! Vamo sair saindo pro Salgueiro porque nós pode...

- Vai ganhar um carro agora com os homi na nossa captura? - interrompeu Inferninho com a voz autoritária. Voltaram a andar pelo mato por algum tempo calados. Depois de passarem pelo campo do Paúra, Inferninho afirmou que teriam de guardar a parte de Inho e, se por acaso ele tivesse dançado, mandariam o dinheiro para a cadeia.

A mudança de uma edição para outra do livro tem grande relação com a produção do filme, relação esta que pode ser constatada logo quando se olha para a capa de cada uma delas. Em 1997, a edição de Cidade de Deus não possuía nenhuma figura de personagem na capa. Já a edição de 2002 - com páginas coloridas - possuía 4 capas diferentes, cada uma com uma fotografia do filme, mostrando cenas em que apareciam personagens importantes como Busca-Pé, Dadinho, Cabeleira e Bené. 
Seria essa atitude uma estratégia de marketing para vender mais livros, já que o filme, por suas próprias características e pela distribuição que teve, se tornou um sucesso de bilheteria? De fato, as vendas aumentaram depois desse episódio e Cidade de Deus, após ter ganhado o mundo nas telas, ganhou o mundo nas prateleiras. O livro foi traduzido para outros idiomas e seguiu o caminho de sucesso conquistado pelo filme.

Mas mudar só a capa não foi suficiente. O corte de mais de 100 páginas de uma edição para outra deixou a narrativa muito mais dinâmica e veloz - o que faz lembrar um filme de ação. Paulo Lins, na entrevista já citada para Heloísa Buarque de Hollanda, faz o seguinte comentário sobre esse aspecto:

\section{HBH: E por que você fez agora essa versão reduzida?}

PAULO: O corte foi para tradução. Mas tinha muita coisa que eu não gostava, muita coisa repetida. Aproveitei e saí cortando. Ficou mais encadeado, acho que ficou melhor.

HBH: Mas é engraçado, porque os escritores se levam muito a sério, e, se o editor pedir para fazerem uma edição mais curtinha, eles provavelmente não vão gostar...

PAULO: Mas eu não me estressei com isso não. Eu sabia que era para melhorar.

Para ele, a segunda edição melhorou. O curioso, porém, é porque para melhorar foi necessário mudar os nomes das personagens? E aí, instala-se uma tensão. O filme foi baseado na primeira edição do livro e a segunda edição foi publicada simultaneamente a estréia do filme em todo país. No entanto, Paulo Lins diz que mudou o nome das personagens para afastar o livro do filme, e aí podemos nos perguntar: mas que maluquice é essa? O livro não tem na capa a foto do ator do filme? Sim, isso é verdade, mas Lins diz: "Literatura é literatura, filme é filme. Quis afastar o livro do filme para o pessoal procurar qual personagem está ou não" (ZERO HORA, 2002).

Assim, o processo de Cidade de Deus apresenta a seguinte cronologia:

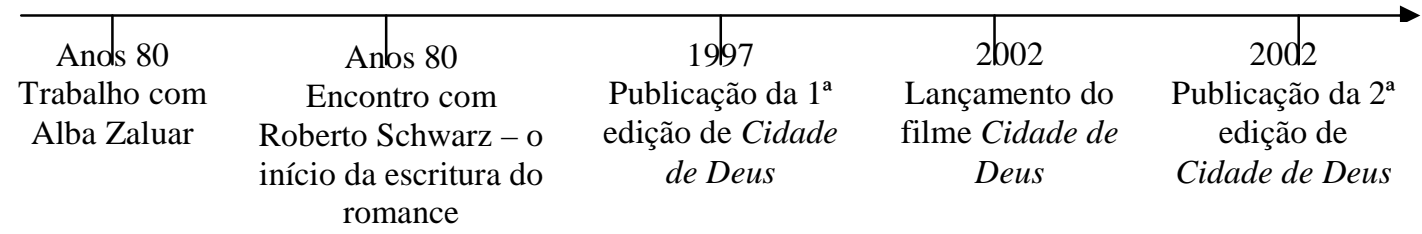

Indubitavelmente ele foge do que encontramos em outros estudos sobre o processo de criação, analisados sob viés da Crítica Genética, já que não falamos de uma obra e seus manuscritos - sendo todo o material de um único autor. Em Cidade de Deus, o processo de criação percorre caminhos que envolvem obras de outros autores e, por que não, de outras naturezas. Mas como não vamos nos aprofundar nessa questão teórica nesse texto, observemos o que a crítica avaliou dessas obras.

Com exceção dos ensaios de Roberto Schwarz e Vilma Areas - que já citamos - a fortuna crítica de Cidade de Deus centra-se fundamentalmente sobre filme, como é o caso de Luiz Zanin Oricchio, que em seu livro Cinema de Novo faz uma análise de Cidade de Deus no processo de retomada do cinema brasileiro. Outros críticos, incluindo Ivana Bentes e João Cezar de Castro 
Rocha, citam a importância do livro e da divergência da narrativa para a composição de uma interpretação. No entanto, nenhum deles estabelece uma leitura profunda acerca deste tema.

Ivana Bentes acredita que Cidade de Deus é mais um dos representantes de um estilo que ela denomina "Cosmética da Fome" (produção de um olhar exótico sobre a miséria e o Brasil); e João Cezar de Castro Rocha propõe uma leitura a partir do que chama "Dialética da Marginalidade", que, para ele, pressupõe uma nova forma de relação entre as classes; não se trata mais de conciliar as diferenças, mas de evidenciá-las.

Mas, de repente, parece que a crítica nem sempre começa quando o a literatura termina. Vilma Areas toca em um ponto no seu ensaio para o qual queremos chamar a atenção: a relação de Roberto Schwarz com a publicação de Cidade de Deus. Vilma fala da importância desse crítico para que o livro fosse lido, recebido e despertasse o interesse dos leitores críticos do país:

\begin{abstract}
Tamanho interesse - afinal não passava de um livro de estréia - opôs juízos equilibrados, alguns mesmo surpreendidos, o que conta ponto para o livro, a outros francamente indispostos: a poeira levantada teria sido obra não do próprio, mas da influência indiscutível de Roberto Schwarz no campo intelectual. (A tempo: a indicação editorial foi também de Alba Zaluar). Defeitos, nem sempre inexistentes, foram pescados aqui e ali como prova de que Paulo Lins não é do ramo e frisou-se de maneira reveladora, segundo penso, o apelido de "Paulo Maluco". A mesa redonda do Boletim publicado pela Universidade de Brasília e que acolheu artigos eloqüentes no calor da hora, contra e a favor, num louvável esforço de isenção à semelhança de $O$ Estado de São Paulo, acabou fechando a folha de rosto com uma afirmativa solta do autor ("Não sou intelectual. Sou escritor") a sublinhar com certeza sua compreensão mediana e equivocada do ofício (AREAS, 1998).
\end{abstract}

ATRÁS DE UM GRANDE HOMEM EXISTE SEMPRE UMA GRANDE MULHER, ATRÁS DE UM ESCRITOR EXISTE...

Roberto Schwarz foi o grande responsável pela publicação de Cidade de Deus. Como já vimos acima, num trecho da entrevista de Lins a Heloísa Buarque de Hollanda, Schwarz o orientou a escrever um romance e deixar de lado a poesia, pediu para que Paulo Lins colocasse sentimento no que escrevia e ele colocou. Enfim, Roberto Schwarz observou muito de perto toda a construção da obra.

Na mesma entrevista, Paulo Lins ainda revela:

HBH: Mas volto para o início da conversa: como você sabia que esse romance ia ter tanta repercussão? Que ia mudar sua vida?

PAULO: Pela própria natureza do livro. Do jeito como ele foi feito, da aventura que foi. E o Roberto Schwarz, na verdade, me deu essa segurança.

HBH: Nessa época você já tinha a Companhia das Letras interessada?

PAULO: Não, foi o Roberto que levou o livro para a editora. Roberto fez tudo! Ele conseguiu a bolsa, levou o livro na editora...

HBH: Deu um dinheirinho...

PAULO: E ainda me perguntou qual a editora que eu preferia, imagina! Antes de o livro ser publicado, ele disse que o livro ia ser traduzido no mundo todo, que ia 
virar filme... E isso foi legal, porque eu tinha essa intuição, o Roberto veio e fez uma afirmação.

HBH: Acho que o Roberto estava esperando que esse livro aparecesse há muito tempo. Ele organizou um livro importante sobre o pobre na literatura brasileira. Mas ainda eram reflexões sobre a representação do pobre na literatura. Imagina quando ele descobre um pobre com voz literária? Apostou forte nisso. Porque o que "Cidade de Deus" oferece não é um assunto novo, mas uma voz nova.

PAULO: É o olhar interno e acadêmico ao mesmo tempo. Porque eu estava e vivia a academia, mas estava também lá com a bandidagem, eu conhecia aquilo lá.

HBH: Como é que você deu ponto final no "Cidade de Deus"? Como é que você reconheceu que o livro estava pronto?

PAULO: Eu nunca falei isso, é muito íntimo, mas para você eu falo. Cheguei num ponto em que entrei numa crise terrível, porque não sabia como acabar. $\mathrm{E}$ além disso eu estava mal, não ganhava dinheiro, tinha acabado de me separar de minha mulher, um inferno. Um dia me senti tão mal que fui até a Colônia Juliano Moreira e pedi um psiquiatra. Aí falei, falei e ele só me disse uma coisa: "Você vai para casa e vai acabar esse romance!". Voltei para casa e acabei o romance.

HBH: Quantos exemplares já foram vendidos?

PAULO: 80 mil, mais ou menos.

As palavras de Paulo Lins mostram uma dimensão da relação entre autor e crítico, obra e crítica, que, até então, não tínhamos notícia na literatura brasileira. $\mathrm{O}$ texto literário aqui não é apenas um objeto de análise do crítico, é talvez quase um objeto produzido pelo crítico para sua análise. Se pensarmos em produções musicais e fizermos uma comparação análoga, podemos dizer que Paulo Lins é o escritor de Cidade de Deus e Roberto Schwarz o produtor.

Essa relação não é citada somente nessa entrevista. Paulo Lins sempre creditou a Roberto Schwarz a escritura de seu romance. Num Colóquio realizado na Universidade de São Paulo, em 2003, em homenagem ao crítico, o autor comentou todo o percurso - inclusive financeiro - dessa relação.

De fato, a posição de Roberto Schwarz como crítico literário - respeitado e aclamado no meio literário nacional - foi fator intercessor e decisivo na publicação do romance. Cidade de Deus teria sido escrito e publicado sem a interseção de Roberto Schwarz? O que podemos inferir é que o bom relacionamento de Schwarz com o mercado editorial foi condição primordial para que o livro de um jovem e desconhecido escritor fosse publicado por uma editora grande e respeitada. A frase de Paulo Lins, Roberto fez tudo! Ele conseguiu a bolsa, levou o livro na editora (...) E ainda me perguntou qual a editora que eu preferia, imagina!, corrobora essa hipótese.

Como Schwarz acreditava na importância dessa obra, ele também foi responsável pela conquista da bolsa Vitae por Paulo Lins, que proporcionou o dinheiro necessário para que livro fosse concluído. E claro, com o livro pronto, a certeza de que haveria o filme, as traduções etc., etc.

Heloísa Buarque de Hollanda, ao ouvir esse relato de Lins, pontua uma questão:

Acho que o Roberto estava esperando que esse livro aparecesse há muito tempo. Ele organizou um livro importante sobre o pobre na literatura brasileira. Mas ainda eram reflexões sobre a representação do pobre na literatura. Imagina 
quando ele descobre um pobre com voz literária? Apostou forte nisso. Porque o que "Cidade de Deus" oferece não é um assunto novo, mas uma voz nova.

Talvez tenha sido realmente esse o interesse de Schwarz sobre Paulo Lins e sobre sua obra. Talvez ele, como crítico e intelectual, por mais que observasse as relações entre os pobres, os favelados, o crime e a criminalidade - temas de Cidade de Deus - não conseguisse um resultado convincente. Apostar em Paulo Lins seria mais certo, pois ele vivia lá, conhecia as brigas dos bandidos, sabia o que realmente se passava naquele espaço. Schwarz circulava pelos corredores escuros das Universidades, onde sobrevivem brigas teóricas com muitos argumentos e pouco diálogo.

Mas como esse texto já está ficando muito grande para um artigo...

Cidade de Deus, sem dúvida, deu certo. Até 2003, 80 mil exemplares vendidos. O livro foi, no mínimo, eloqüente. Provocou inúmeros debates e discussões, mas ainda é necessário voltar às questões relacionadas à crítica e à produção literária. O próximo passo é, então, explorálas. $\mathbf{c}^{\mathrm{G}}$

\section{Referências bibliográficas :}

AREAS, Vilma. "Errando nas quinas de Cidade de Deus". In. Praga: estudos marxistas. Maio, 1998. Edição nº 5.

CIDADE DE DEUS - filme. Direção: Fernando Meirelles. Co-direção: Katia Lund. Roteiro: Bráulio Mantovani.

LINS, Paulo. Cidade de Deus. São Paulo: Companhia das Letras, 1997. pág. 549.

RETRATO EM PEDAÇOS DE UMA CIDADE. Entrevista de Paulo Lins para Heloisa Buarque de Hollanda. In Revista Indiossincrasia. Rede Internet, Portal Literal. 11/07/2003.

SCHWARZ, Roberto. Seqüências Brasileiras. Companhia das Letras: São Paulo, 1999.

VIDA NA PERIFERIA GANHA ESPAÇO NA LITERATURA. por Patrícia Rocha, Jornal Zero Hora, 9/11/2002

ZALUAR, Alba. A Máquina e a Revolta. $2^{\mathrm{a}}$ edição. São Paulo: Brasiliense, 2000. 